\title{
Solid-Supported Fluoroboric Acid: An Efficient Reagent Combination for S-Alkylation of Thiols
}

\author{
RAMKISHAN N. ADUDE ${ }^{\mathrm{a}}$, SANTOSH V. GOSWAMI ${ }^{\mathrm{a}}$, \\ B. Y. PAGARE ${ }^{\mathrm{b}}$ and SUDHAKAR R. BHUSARE ${ }^{\mathrm{a}^{*}}$
}

${ }^{a}$ Department of Chemistry, Dnyanopasak College, Parbhani-431401, India

${ }^{\mathrm{b}}$ Department of Chemistry, Shri Anand College, Pathardi, Ahamadnagar-444102, India

bhusare71@yahoo.com

Received 4 June 2012 / Accepted 22 June 2012

Abstract: The solid-supported fluoroboric acid $\left(\mathrm{SiO}_{2}-\mathrm{HBF}_{4}\right)$ was found to be a mild and highly effective catalyst for $s$-alkylation of thiols with alcohols under solvent free condition.

Keywords: S-Alkylation, Fluoroboric acid, Solvent free, Silica gel, Thiols, Thioethers

\section{Introduction}

Thioether is an important synthetic intermediate in both bioorganic and organic chemistry. Cyclic analogues of acyclic polypeptides prepared from thioether linkage restrict their conformational mobility and thus to increase their biological activity and stability against biodegradation ${ }^{1-4}$. Thioethers are also used as hetero atomic functional groups in organic synthesis, such as, oxidation of thioethers, chiral sulfoxides generated can be used as auxiliaries, in asymmetric synthesis ${ }^{5-8}$. Sulfones have been employed for stabilizing $\alpha$-radicals and $\alpha$-anions ${ }^{9}$ can act as cationic synthons ${ }^{10}$ and also for the formation of C-C bonds ${ }^{11}$.

Various protocols are available for the synthesis of thioethers such as, deoxygenating of sulfoxides ${ }^{12}$, displacement of leaving groups with sulfur nucleophiles ${ }^{13}$, addition of thiols to carbonyl compounds followed by in situ reduction of the generated intermediate thionium ion $^{14}$, anti-Markovnikov addition of alkene and alkane-thiols to alkenes ${ }^{15}$, Mitsunobu type reactions ${ }^{16}$, metal-mediated cross-coupling process ${ }^{17}$ and metal catalyzed hydrothiolation of alkynes $^{18}$.

In most of the cases, thioethers have been prepared using expensive and commercially unavailable materials, hazardous and corrosive compounds such as, alkylating agents, strong reducing agents, harsh reaction conditions and involve tedious work-up procedures ${ }^{19}$. Additionally, some of the reported methods can not be used for the preparation of different structurally and electronically diverse thioethers. For example, by applying modified 
Mitsunobu conditions using liquid trimethylphosphine combined with 1,1'-(azodicarbonyl)dipiperidine in the presence of imidazole, aliphatic thiols react only with primary alcohols to give thioethers, other types of thiols and alcohols did not gives any reaction.

As part of our research to develop an efficient and environmentally benign application of silica supported fluoroboric acid to minimize the amount of harmful organic solvents used in chemical processes, much attention has been devoted to the use of an alternatives reaction media. Besides the use of supercritical fluids, water, ionic liquids and the possibly performing chemical processes under solvent free conditions has been received more attention. Since organic sulfur compounds have become increasingly useful and important in organic synthesis, the developments of convenient and efficient protocol for the preparation of appropriate sulfides, which carry other functional group, are in high demand. The leading contender for an environmentally acceptable alternative is supported reagent which have good thermal and mechanical stabilities can be easily handled as they are invariable low toxic, non corrosive free flowing powders, less costly and easily separated from the reaction mixture. Consequently the solvent less protocol with supported reagents provides an excellent tool for achieving environmentally friendly economical organic synthesis. Interest in developing true catalyst using inexpensive and non-polluting reagent, we wish to report $\mathrm{SiO}_{2}-\mathrm{HBF}_{4}$ promoted S-alkylation of alcohol with thiols at room temperature under solvent free conditions (Scheme 1).

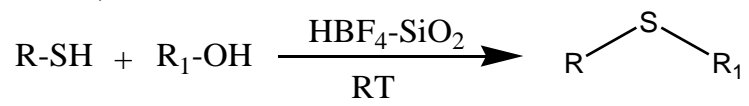

\section{Experimental}

Scheme 1. S-Alkylation of thiols with alcohols

All chemicals were purchased from Sigma-Aldrich chemical companies. The progress of the reactions was followed by TLC using silica gel Merck $60 \mathrm{~F}_{254}$ plates. Melting points were recorded on open capillaries and are uncorrected. The ${ }^{1} \mathrm{H}$ NMR spectra were recorded on a varian $300 \mathrm{MHz}$ spectrometer using $\mathrm{CDCl}_{3}$ as solvent. The mass spectra were scanned on a Shimadzu LCMS-2010 EV instrument at $70 \mathrm{eV}$.

\section{General procedure for S-alkylation of thiols}

To a mixture of thiols $(1.1 \mathrm{mmol})$, alcohols $(1 \mathrm{mmol})$ and freshly prepared silica gel supported fluoroboric acid in catalytic amount was added (2 mol \%) and the reaction mixture was stirred at room temperature for appropriate time (Table 1). After completion of reaction indicated by thin layer chromatography (pet ether : ethyl acetate 9:1 ), the solvent was evaporated and residue was dissolved in $25 \mathrm{~mL}$ water and $100 \mathrm{~mL}$ ethyl acetate, the organic layer was dried over $\mathrm{Na}_{2} \mathrm{SO}_{4}$ and evaporated under reduced pressure to give the corresponding $S$-alkylated product which was purified by triturating with ether.

\section{Selected spectral data of thioethers}

Benzyl (p-tolyl) sulfane (Table 1, entry 1): ${ }^{1} \mathrm{H}$ NMR $\left(\mathrm{CDCl}_{3}, 300 \mathrm{MHz}\right): \delta 2.26$ (s, 3H), 4.15 (s, 2H), 7.12-7.68 (m, 9H); MS (m/e): $214[\mathrm{M}]^{+}$; Anal. Calcd for $\left(\mathrm{C}_{14} \mathrm{H}_{14} \mathrm{~S}\right): \mathrm{C}, 78.46 ; \mathrm{H}$, 6.58. Found: C,78.45; H, 6.60 .

Benzyl (cyclohexyl) sulfane (Table 1, entry 5): ${ }^{1} \mathrm{H}$ NMR $\left(\mathrm{CDCl}_{3}, 300 \mathrm{MHz}\right): \delta 0.84$ (m, 6H), 1.34 (m, 4H), 1.52 (m, 1H), 4.20 (s, 2H); MS (m/e): $206[\mathrm{M}]^{+}$; Anal. Calcd for $\left(\mathrm{C}_{13} \mathrm{H}_{18} \mathrm{~S}\right)$ : C, 75.67; H, 8.79. Found: C, 75.65; H, 8.81. 
(2-(Biphenyl-4-yl) propan-2-yl) (p-tolyl) sulfane (Table 1, entry 9): ${ }^{1} \mathrm{H}$ NMR $\left(\mathrm{CDCl}_{3}\right.$, $300 \mathrm{MHz}): \delta 1.66(\mathrm{~s}, 6 \mathrm{H}), 2.27(\mathrm{~s}, 3 \mathrm{H})$ 6.94-7.66 (m, 13H); MS (m/e): $318[\mathrm{M}]^{+}$; Anal. Calcd for $\left(\mathrm{C}_{22} \mathrm{H}_{22} \mathrm{~S}\right)$ : C, 82.97; H, 6.96. Found: C, 82.96; H, 6.98.

Benzhydryl (p-tolyl) sulfane (Table 1, entry 10): ${ }^{1} \mathrm{H}$ NMR $\left(\mathrm{CDCl}_{3}, 300 \mathrm{MHz}\right): \delta 2.26$ (s, 3H), 5.49 (s, 1H), 7.15-7.49 (m, 14H); MS (m/e): $290[\mathrm{M}]^{+}$; Anal. Calcd for $\left(\mathrm{C}_{20} \mathrm{H}_{18} \mathrm{~S}\right)$ : C, 82.71; H, 6.25. Found: C, 82.73; H, 6.28.

(Table 1, entry 16): ${ }^{1} \mathrm{H}$ NMR $\left(\mathrm{CDCl}_{3}, 300 \mathrm{MHz}\right): \delta 1.41-1.99(\mathrm{~m}, 15 \mathrm{H}), 2.39(\mathrm{~s}, 3 \mathrm{H})$, 7.08 (d, 2H), 7.39 (d, 2H); MS (m/e): $258[\mathrm{M}]^{+}$; Anal. Calcd for $\left(\mathrm{C}_{17} \mathrm{H}_{22} \mathrm{~S}\right): \mathrm{C}, 79.01 ; \mathrm{H}$, 8.58. Found: C, 79.03; H, 8.61.

\section{Results and Discussion}

Initial studies were carried out by condensation of benzyl alcohol with 4-methylthiophenol as a model reaction in the presence of $\mathrm{SiO}_{2}-\mathrm{HBF}_{4}$. We observed that a sticky reaction mixture was obtained with the formation of corresponding thioether around 50-60\% yield. Increasing the reaction time did not affect the yield of the product. We found that using benzyl alcohol (1 mmol), 4-methylthiophenol $(1.1 \mathrm{mmol})$ and $\mathrm{SiO}_{2}-\mathrm{HBF}_{4}(2 \mathrm{~mol} \%)$ in the absence of solvent, the reaction proceed very cleanly at room temperature and corresponding thioether was isolated in $92 \%$ yield.

The present method is applicable for the synthesis of thioethers from the reaction of cinnamyl alcohol, adamantanol structurally and electronically diverse benzyl alcohols with aromatic or aliphatic thiols and also with dithiols. An electronic factor plays a significant role in these $S$-alkylation reactions. Aromatic alcohols with electron donating groups reacted faster than those substituted with electron withdrawing groups and also provided the thioethers in higher yields (Table 1, entries 6-9). This method is helpful for the preparation of dithioether using dithiols (Table 1, entry 21 and 22). The method is also used for the efficient preparation of dithioethers (Table 1 and entry 23), which could be used as precursors for the preparation of macro cyclic or polymeric sulfur containing compounds.

In addition the reaction of 2-(4-biphenyl-4-yl)-2-propanol [Table 1, entry 9] was not accompanied by the production of it's corresponding olefin as an elimination byproduct. The low yield and slow rate of reaction involving 4-nitrobenzyl alcohol is an indication of the generation of an unstable partially positively charged intermediate (Table 1, entry 8).

Table 1. S-Alkylation of thiols using $\mathrm{SiO}_{2}-\mathrm{HBF}_{4}$ under solvent free conditions

Entry Alcohols


5.<smiles>SC1CCCCC1</smiles>

6.<smiles>COc1ccc(CO)cc1</smiles><smiles>Cc1ccc(S)cc1</smiles><smiles>c1ccc(CSC2CCCC2)cc1</smiles>
87

7.<smiles>OCc1ccc(Cl)cc1</smiles><smiles>Cc1ccc(S)cc1</smiles><smiles>COc1ccc(CCc2ccc(C)cc2)cc1</smiles>

8.<smiles>O=[N+]([O-])c1ccc(CO)cc1</smiles><smiles>Cc1ccc(S)cc1</smiles><smiles>Clc1ccc(SCc2ccccc2)cc1</smiles>

9.<smiles>CC(C)(C)c1ccc(-c2ccccc2)cc1</smiles><smiles>Cc1ccc(S)cc1</smiles><smiles>Cc1ccc(CSc2ccc([N+](=O)[O-])cc2)cc1</smiles>
$45 \quad 55$

10.<smiles>Sc1ccc(I)cc1</smiles><smiles>Cc1ccc(SC(C)(Sc2ccc(Br)cc2)c2ccc(I)cc2)cc1</smiles>

$5 \quad 90$

11.<smiles>OC/C=C/c1ccccc1</smiles><smiles>Cc1ccc(S)cc1</smiles><smiles>Cc1ccc(SCc2ccccc2)c(CCc2ccccc2)c1</smiles>

$4 \quad 91$

12.<smiles>O/C=C/c1ccccc1</smiles><smiles>Sc1ccccc1</smiles>

13.<smiles>OC/C=C/c1ccccc1</smiles><smiles>CCCCCS</smiles><smiles>Cc1ccc(SCC=Cc2ccccc2)cc1</smiles>

14.<smiles>SC1CCCCC1</smiles>

15.<smiles>CC(C)(C)O</smiles><smiles>Cc1ccc(S)cc1</smiles><smiles>C(=C/c1ccccc1)\CSc1ccccc1</smiles>

$12 \quad 91$

16.<smiles>OC12CC3CC(C1)C(C3)C2</smiles><smiles>Cc1ccc(S)cc1</smiles><smiles>CCCCCSCC=Cc1ccccc1</smiles>

895

17.<smiles>OC12CC3CC(C1)C2C3</smiles><smiles>Sc1ccccc1</smiles><smiles>C(C/C=C/c1ccccc1)=S1CCCC1</smiles>

5

18.

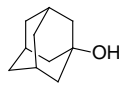

SH<smiles>Cc1ccc(SC(C)(C)C)cc1</smiles>

$12 \quad 83$

19. $\mathrm{N}_{\mathrm{OH}}$<smiles>CCCCCS</smiles><smiles>Cc1ccc(SC23CCC(CC2)C3)cc1</smiles>

$8 \quad 93$

20. $\mathrm{SOH}$<smiles>SC1CCCCC1</smiles><smiles>c1ccc(SC23CC4CC(C2)C(C4)C3)cc1</smiles>

$15 \quad 96$

21. $\mathrm{S}_{\mathrm{OH}} \mathrm{HS}_{\mathrm{SH}}$<smiles>c1ccc(CSCC23CC4CC(C2)C(C4)C3)cc1</smiles>

35 92

22. MeO<smiles>CCCCCSC12CC3CCC(C3)C1C2</smiles>

$12 \quad 90$

23.<smiles>CCCCCSC12CC3CC(C1)C(C3)C2</smiles>

$10 \quad 91$

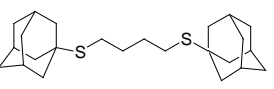
$20 \quad 93$

\section{${ }^{a}$ Isolated yield}




\section{Conclusion}

In summary, we report an environmentally friendly, simple and highly efficient method for the regioselective s-alkylation using thiols with alcohols under solvent free conditions using an inexpensive and novel catalyst. The salient features of the present protocol are mild reaction conditions, greater regioselectivity, cleaner reaction profile, excellent yield with experimental simplicity, which makes it potentially useful for the industrial applications.

\section{Acknowledgement}

We acknowledge Dr. P. L. More, Dnyanopasak College, Parbhani for his constant encouragement and Financial support for this work by DST-SERC, New Delhi (SR/FT/CS023/2008) is highly appreciated.

\section{References}

1. $\quad$ Moberg H I and Omnaas J R, J Am Chem Soc., 1985, 107, 2986.

2. Hurby V J, Al-Obeidi F and Kazmierski W, Biochem J., 1990, 268, 249-262.

3. Kataoka T, Beusen D D, Clark J D, Yodo M and Marshall G R, Biopolymers, 1992, 32(11), 1519-1533.

4. Hurby V J and Bonner G G, Methods Mol Biol., 1994, 35, 201-240.

5. Solladie G, Synthesis, 1981, 185.

6. Mata E G, Phosphorus, Sulfur Silicon, 1996, 117, 231.

7. Carreno M C, Chem Rev., 1995, 95(6), 1717-1760.

8. Paquette L A, Synlett., 2001, 1.

9. a) Najera C and Sansano J M, Recent Res Develop Org Chem., 1998, 2, 637; b) Chinchila R and Najera C, Recent Res Develop Org Chem., 1997, 1, 437-467.

10. Yao Q, Org Lett., 2002, 4, 427.

11. Madesclaire M, Tetrahedron, 1988, 44, 6537.

12. Nicolaou K C, Koumbis A E, Snyder S A and Simonsen K B, Angew Chem Int Ed., 2000, 39(14), 2529-2533.

13. a) Dowsland J, Mckerlie F and Procter D J, Tetrahedron Lett., 2000, 41, 4923-4926;

b) Procter D J, Archer N J, Needham R A, Marchington A P and Rayner C M, Tetrahedron, 1999, 55, 9611-9622.

14. Kumar P, Pandey R K and Hedge V R, Synlett., 1999, 1921.

15. a) Chelucci G, Culeddu N, Saba A and Valenti R, Tetrahedron: Asymmetry, 1999, 10, 3537-3546; b) Falck J R, Lai J Y, Cho S D and Yu J, Tetrahedron Lett., 1999, 40, 2903-2906.

16. a) Garofalo A, Campiani G, Fiorini I and Nacci V, Tetrahedron, 1999, 55, 1479-4790;

b) Shibata K, Yamaga $\mathrm{H}$ and Misunobu O, Heterocycles, 1999, 50(2), 947-967;

c) Palomo C, Oiarbide M, Lopez R and Gomez-Bengo E, Tetrahedron Lett., 2000, 41, 1283-1286; d) Zaragoza F, Tetrahedron, 2001, 57, 5451; e) Herradura P S, Pendola K A and Guy R K, Org Lett., 2000, 2, 2019-2022.

17. a) Wendeborn S, De Mesmaeker A, Brill W K and Berteina S, Acc Chem Res., 2000, 33(4), 215-224; b) Savarin C, Srogl J and Liebeskind L S, Org Lett., 2002, 43094312; c) Ogawa A, Ikeda T, Kimura K and Hirao T, J Am Chem Soc., 1999, 121, 5108-5114.

18. a) Procter D J, J Chem Soc., Perkin Trans 1, 2000, 835-871; b) Procter D J, J Chem Soc Perkin Trans 1, 2001, 335.

19. Firouzabadi H, Iranpoor N and Karimi B, Synlett., 1999, 319. 